Tahun XI, No. 20, April 2015

\title{
PENERAPAN MEDIA BONEKA TANGAN DALAM PEMBELAJARAN MENGONVERSI TEKS LAPORAN HASIL OBSERVASI MENJADI TEKS DIALOG PADA SISWA SEKOLAH MENENGAH ATAS
}

\author{
Mimas Ardhianti \\ Dosen Prodi PBSI - FKIP - Universitas PGRI Adi Buana Surabaya \\ mimasardhianti@ymail.com
}

\begin{abstract}
This study aimed to describe the implementation and results of the application of Hand Puppet media in speech class X Ak-2 SMK Antartika 2 Sidoarjo. Media Hand Puppet is a puppet hand puppet media is driven by a person with the way the rest of his fingers put under clothes doll is used as a learning medium education for children who are used to deliver the message in the storytelling. Research using qualitative descriptive technique. Data were taken for this study is based on the observation sheet and questionnaire. While the source of the data taken at 42 Grade X Ak-2 SMK Antartika 2 Sidoarjo. From the observation and questionnaires can be seen that the results of learning by applying Hand Puppets media can assist students in learning Indonesian. There is $97.6 \%$ of students whose value meets the minimum passing standard. Meanwhile, $2.3 \%$ of students value does not meet the minimum passing standard for their speaking ability is still lacking. The students become more actively talking with the media application Hand Puppet.
\end{abstract}

Keywords: Media Puppets Hand, Speech

\section{A. PENDAHULUAN}

Terdapat empat keterampilan dalam berbahasa, antara lain keterampilan mendengarkan atau menyimak, keterampilan berbicara, keterampilan membaca, dan terakhir adalah keterampilan menulis. Di antara keempat keterampilan tersebut, keterampilan berbicara merupakan keterampilan yang masih menjadi kendala untuk peserta didik. Hal tersebut disebabkan tingkat keterampilan berbicara menuntut kemahiran keterampilan yang lain.

Keterampilan berbicara diperlukan pada materi mengonversi teks laporan observasi menjadi teks dialog. Kemampuan tersebut sangat penting dikuasai khususnya bagi para peserta didik tingkat SMA. Selain menjadi bahasan materi yang diwajibkan dalam kurikulum, keterampilan berbicara diperlukan pada teks laporan observasi agar peserta didik mampu berdialog.

Sayangnya, kemampuan berbicara peserta didik SMA dirasa masih kurang bagus. Hal itu ditandai dengan banyaknya kebingungan mengenai bagaimana dan apa yang dilaporkan dalam kegiatan mengonversi teks laporan observasi. Maka dari itu, dibutuhkan media pembelajaran yang sesuai sehingga dapat membantu perserta didik dalam kegiatan belajar-mengajar. Salah satu media yang sesuai adalah boneka tangan.

Boneka tangan adalah boneka yang ukurannya lebih besar dari boneka jari dan bisa dimasukkan ke tangan. Jari tangan bisa dijadikan pendukung gerakan tangan dan kepala boneka (Gunarti, 2010:5).Bermain boneka tangan dapat melatih imajinasi, perkembangan bahasa reseptif dan ekspresif, dapat membantu anak menarik benang merah antara anak dan lingkungan sosial yang lebih luas.

Berdasarkan uraian di atas, materi mengenai mengonversi teks laporan observasi menjadi teks dialog perlu untuk dikaji dan dibahas lebih lanjut. Dengan adanya pembahasan ini, diharapkan bermanfaat dan mampu memberikan pemahaman dan penjelasan kepada para peserta didik seputar mengonversi teks laporan observasi. Oleh karena itu, penulis mengangkat judul 
"Penerapan Media Boneka Tangan Dalam Pembelajaran Mengonversi Teks Laporan Hasil Observasi Menjadi Teks Dialog”.

\section{B. KAJIAN PUSTAKA}

Media mengarah pada sesuatu yang mengantar/meneruskan informasi (pesan) antara sumber (pemberi pesan) dan penerima pesan. Media dapat dijadikan segala bentuk dan saluran yang dapat digunakan dalam suatu proses penyajian informasi. Heinich, dkk.(1996:6) mengemukakan definisi medium sebagai sesuatu yang membawa informasi antara sumber (source) dan penerima (receiver) informasi. Sedangkan, Kemp dan Dayton (1985:3), mengemukakan bahwa peran media dalam proses komunikasi adalah sebagai alat pengirim (transfer) yang mentransmisikan pesan dari pengirim (sander) kepada penerima pesan atau informasi (receiver).Jerold Kemp (dalam Pribadi, 2004:14) mengemukakan beberapa faktor yang merupakan karakteristik dari media, a) kemampuan dalam menyajikan gambar (presentation), b) faktor ukuran (size); besar atau kecil, c) faktor warna (color): hitam putih atau berwarna, d) faktor gerak: diam atau bergerak, f) faktor bahasa: tertulis atau lisan, g) faktor keterkaitan antara gambar dan suara: gambar saja, suara saja, atau gabungan antara gambar dan suara.

Sehungan dengan teori di atas, Jerold Kemp dan Diane K. Dayton (dalam Pribadi,2004:1.5) mengemukakan klasifikasi jenis media yakni, a) media cetak, b) media yang dipamerkan (displayed media), c) overhead transparency, d) rekaman suara, e) slide suara dan film strip, f) presentasi multi gambar, g) video dan film, h) pembelajaran berbasis komputer (computer based learning). Pada umumnya keberadaan media muncul karena keterbatasan kata-kata, waktu, ruang, dan ukuran.Ditambahkan juga bahwa media pembelajaran berfungsi sebagai sarana yang mampu menyampaikan pesan sekaligus mempermudah penerima pesan dalam memahami isi pesan.Menurut AECT (Miarso, 2004:10), media atau bahan adalah barang- barang yang biasanya berisikan pesan untuk disampaikan dengan menggunakan peralatan, kadang-kadang bahan itu sendiri sudah merupakan bentuk penyajian.

Miarso (2004:457) menyatakan bahwa media pendidikan adalah berbagai jenis komponen dalam lingkungan peserta didik untuk belajar.Miarso (2004:458) menyatakan bahwa model pembelajaran adalah segala sesuatu yang digunakan untuk menyalurkan pesan serta dapat merangsang pikiran, perasaan, perhatian, dan kemauan si belajar sehingga dapat mendorong terjadinya proses belajar yang disengaja, bertujuan dan terkendali. Sadirman (1996:7) berpendapat bahwa media adalah segala sesuatu yang dapat digunakan untuk menyalurkan pesan dari pengirim ke penerima sehingga dapat merangsang pikiran, perasaan, perhatian, dan minat, serta perhatian peserta didik sedemikian rupa sehingga proses belajar terjadi.Briggs (Sadirman, 1996:6) berpendapat bahwa media adalah segala alat fisik yang dapat menyajikan pesan serta merangsang peserta didik untuk belajar, misalnya buku, film, kaset, film bingkai.Gerlach dan Ely (Arsyad, 2005:3) berpendapat bahwa media adalah manusia, materi, atau kejadian, atau kejadian yang membangun kondisi yang membuat peserta didik mampu memperoleh pengetahuan, keterampilan, atau sikap.

Berdasarkan beberapa pendapat di atas, maka dapat disimpulkan bahwa media pembelajaran merupakan media yang dapat digunakan untuk kegiatan pembelajaran sebagai penunjang keberhasilan pembelajaran.

Media yang digunakan dalam peeltian ini adalah media boneka. Boneka merupakan sebuah permainan yang popular di kalangan anak-anak di berbagai belahan dunia.Boneka sebagai salah satu benda mainan yang berbentuk tiruan makhluk yang ada di dunia (biasanya tiruan manusia atau hewan) bisa terbuat dari bahan yang sederhana seperti kardus, kain, tanah liat, hingga bahan modern buatan pabrik.

Boneka dalam bahasa Perancis dengan marionette ada dua bentuk, yaitu: (1) tubuh yang dihubungkan dengan lengan, kaki, 
badannya digerakkan dari atas dengan tali-tali atau kawat-kawat halus; (2) boneka yang digerakkan dari bawah oleh seseorang yang tangannya dimasukkan ke bawah pakaian boneka. Boneka yang digerakkan dengan talitemali disebut maronette, sedangkan boneka yang digerakkan oleh tangan disebut boneka tangan (Sudjana, 2002:188).

Menurut Risnayanti, (dalam Triutami, 2004),bahwa media boneka tangan adalahboneka yang digunakan dalam jeniskegiatan pendidikan bahasa yang tidakbegitu mudah pelaksanaannya karena memerlukan keterampilan tertentu dari guru.Bermain boneka tangan dapat melatih imajinasi, perkembangan bahasa reseptif dan ekspresif, dapat membantu anak menarik benang merah antara anak dan lingkungan sosial yang lebih luas.Dikemudian hari permainan ini membantu anak berani berpikir dengan persepektif berbeda lewat pengalaman sehari-hari.Selain itu dengan boneka tangan dapat memperkaya daya imajinasi anak, merangsang berpikir kreatif dan dapat bermain peran sesuai tokoh dalam film favoritnya. (http://www.ayahbunda_online.com//infoayah bunda/search_detail_asp).

Boneka tangan adalah boneka yang ukurannya lebih besar dari boneka jari dan bisa dimasukkan ke tangan. Jari tangan bisa dijadikan pendukung gerakan tangan dan kepala boneka (Gunarti, 2010:20).Jadi pengertian media boneka tangan adalah boneka dijadikan sebagai media atau alat bantu yang digunakan guru dalam kegiatan pembelajaran, yang ukurannya lebih besar dari boneka jari dan bisa dimasukkan ke tangan.

Maka dari itu, keuntungan dari bermain dapat membentuk (a) meningkatkan motivasi, minat, percaya diri dan membantu membentuk kepribadian anak; (b) belajar menggunakan bahasa dengan baik agar dapat menjalin pertemanan (perkembangan emosional); (c) meningkatkan kemampuan bicara; (d) belajar mengungkapkan diri secara spontan; (e) memiliki kekuatan ingatan pendengaran; (f) memahami, menghubungkan dan mengutarakan pengetahuannya dalam bentuk bahasa yang ekspresif.
Materi dalam penelitian ini adalah teks hasil observasil Teks merupakan satuan bahasa yang mengandung pikiran dengan struktur yang lengkap. Salah satu bagian dari teks adalah teks laporan hasil observasi.Purwitasari (2014:297) mendefinisikan teks sebagai ungkapan bahasa yang menurut isi, sintaksis, pragmatik merupakan suatu kesatuan. Teks yang baik harus mengungkapkan gagasangagasan atau gambaran-gambaran yang ada dalam kehidupan.Gagasan-gasasan atau gambaran-gambaran tersebut dituangkan dalam bentuk bahasa yang berupa penceritaan, lazimnya dalam bentuk drama dan prosa maupun untaian kata-kata.

Teks laporan adalah teks yang berisi penjabaran umum/melaporkan sesuatu berupa hasil dari pengamatan (observasi).Teks laporan juga disebut teks klasifikasi karena memuat klasifikasi mengenai jenis-jenis sesuatu berdasarkan kriteria tertentu.Jenis teks ini mendeskripsikan atau menggambarkan bentuk, ciri, atau sifat umum seperti benda, hewan, tumbuh-tumbuhan, manusia, atau peristiwa yang terjadi di alam semesta kita.

Dialog merupakan proses komunikasi antara 2 atau lebih agen, dalam dialog makna harus dipertimbangkan agar memenuhi kaidah semantis dan pragmatis http://adrianade. blogspot.com/2013/06/pengertian-dialog.html.

\section{METODE PENELITIAN}

Penelitian ini menggunakan pendekatan deskriptif kualitatif. Jenis dari penelitian ini yaitu bersifat deskriptif. Penelitian deskriptif ini digunakan untuk mendeskripsikan penerapan media Boneka Tangan pada keterampilan berbicara peserta didik kelas X SMK Antartika 2 Sidoarjo.

Subjek penelitian yaitu kelas X Ak-2 yang terdiri atas 45 peserta didik di SMK Antartika 2 Sidoarjo.Data penelitian yang akan diperoleh1) Hasil observasi tentang penerapan media boneka tangan;2) Hasil angket tentang penerapan media boneka tangan; dan 3) Nilai peserta didik.

Instrumen atau alat pengambilan data yang akan digunakan dalam penelitian ini 1) Lembar observasi aktivitas peserta didik dalam 
Tahun XI, No. 20, April 2015

pembelajaran dengan menggunakan media boneka tangan, 2) Lembar respon peserta didik terhadap perangkat pembelajaran media boneka tangan, 3) Hasil belajar peserta didik. Hasil belajar peserta didik setelah menerapkan media boneka tangan diukur dengan (1) kelancaran berbicara, (2) penggunaan gramatika dalam kalimat, dan (3) penggunaan media Boneka Tangan pada saat berbicara.

Prosedur penelitian dalam penelitian ini 1) Meminta surat izin penelitian untuk melaksanakan penelitian, 2) Penyusunan instrumen penelitian yang berupa lembar observasi peserta didik, lembar respon peserta didik terhadap perangkat pembelajaran media boneka tangan, dan lembar hasil belajar peserta didik. 3) Analisis data, data yang akan diperoleh dianalisis oleh peneliti, yaitu denganmengolah data observasipeserta didik, respon peserta didik yang menggunakan media boneka tangan.

Dalam penelitian ini, data akan dikumpulkan dengan teknik 1) Peneliti mengamati dan mengisi lembar observasi tersebut selama kegiatan belajar dan mengajar berlangsung, 2) Data hasil belajar peserta didik, 3) Setelah kegiatan belajar dan mengajar berakhir, peserta didik mengisi angket untuk memberikan tanggapan terhadap penerapan media boneka tangan.

Untuk menjawab rumusan masalah akan digunakan analisis terhadap proses kegiatan belajar mengajar yang meliputi 1) Data hasil observasi akan membantu peneliti untuk mengetahui penerapan media Boneka Tangan, 2) Pengisian lembar observasi dilakukan observer pada saat proses pembelajaran menggunakan media Boneka Tangan, 2) Hasil belajar peserta didik akan diperoleh dari (a) kelancaran berbicara, (b) penggunaan gramatika dalam kalimat, dan (c) penggunaan media Boneka Tangan pada saat berbicara, 3) Angket untuk mengetahui respon peserta didik terhadap pembelajaran menggunakan media Boneka Tangan. Angket diberikan pada masing-masing peserta didik setelah proses pembelajaran berlangsung. Angket yang diberikan merupakan angket tertutup yang berisi delapan butir pertanyaan.

\section{ANALISIS DATA DAN PEMBAHASAN}

\section{Analisis Data}

Pembelajaran di SMK Antartika 2 Sidoarjo dengan menggunakan media Boneka Tangandilaksanakan dalam satu kali pertemuan, yaitu Kamis, 5 Februari 2015. Proses pembelajaran denganmenggunakan media Boneka Tanganberlangsung selama 180 menit, mulai pukul 11.00WIB sampai dengan pukul 14.30 WIB. Peserta didik yang mengikuti pembelajaran berjumlah 42 peserta didik.

Pada saat itu juga penerapan media Boneka Tanganmulai diterapkan olehpeserta didik. Mereka berkelompok yang sudah ditentukan sebelumnya dan terbentuk sepuluh kelompok. Selama proses pelaksanaan pembelajaran berlangsung, peserta didik terlihat sangat aktif dan bersemangat berbicara, meskipun ada beberapa peserta didik yang ribut dengan temannya.

Pada saat peserta didik berbicara di depan kelas dengan menggunakan media Boneka Tangan ini, mereka sangat senang. Mereka saling bertanya secara bergantian berdialog. Setelah penerapan media Boneka Tanganberakhir, guru memberikanrefleksi berupa pertanyaan tentang apa saja yang telah dipelajari peserta didik denganmenggunakan media Boneka Tangan. Sebagian besar peserta didik sangat bersemangat danaktif menyimpulkan hasil belajar dengan baik. Peserta didik menyimpulkan bahwa merekatelah mengerti bagaimana cara berdialog tentang teks laporan hasil observasi.

Peneliti mendapatkan nilai dari proses pembelajaran peserta didik kelas X Ak-3 dengan menggunakan media Boneka Tangan. Penilaian keterampilan berbicara padamedia Boneka Tanganberdasarkan pada tiga aspek yaitu (1) kelancaran berbicara, (2)penggunaan gramatika dalam kalimat, dan (3) penggunaan media Boneka Tangan pada saat berbicara. Tabel berikut merupakan data hasil nilai peserta didik denganmenggunakan media Boneka Tangan. 
Tahun XI, No. 20, April 2015

\begin{tabular}{|l|l|l|l|l|l|}
\hline \multirow{2}{*}{ No. } & \multirow{2}{*}{$\begin{array}{c}\text { Peserta } \\
\text { Didik }\end{array}$} & \multicolumn{3}{|c|}{$\begin{array}{c}\text { Pspek } \\
\text { Penilaian }\end{array}$} & \multirow{2}{*}{ Nilai } \\
\cline { 3 - 5 } & \multicolumn{1}{|c|}{$\mathbf{2}$} & $\mathbf{3}$ & \\
\hline 1 & ILWS & 82 & 82 & 83 & 82,3 \\
\hline 2 & IMOS & 86 & 85 & 87 & 86,0 \\
\hline 3 & IMOCT & 83 & 83 & 82 & 82,7 \\
\hline 4 & INYR & 80 & 82 & 84 & 82,0 \\
\hline 5 & INGN & 82 & 82 & 85 & 83,0 \\
\hline 6 & INPSR & 84 & 84 & 86 & 84,7 \\
\hline 7 & INGPR & 83 & 83 & 85 & 83,7 \\
\hline 8 & IRYLK & 80 & 80 & 82 & 80,7 \\
\hline 9 & IRTJL & 84 & 84 & 85 & 84,3 \\
\hline 10 & JGRS & 82 & 82 & 85 & 83,0 \\
\hline 11 & KSMR & 86 & 86 & 86 & 86,0 \\
\hline 12 & KIVN & 84 & 84 & 82 & 83,3 \\
\hline 13 & LMH & 83 & 82 & 85 & 83,3 \\
\hline 14 & LPRA & 86 & 86 & 86 & 86,0 \\
\hline 15 & LNTI & 72 & 70 & 85 & 75,7 \\
\hline 16 & LCID & 83 & 82 & 85 & 83,3 \\
\hline 17 & LSTM & 82 & 82 & 82 & 82,0 \\
\hline 18 & LGD & 84 & 84 & 86 & 84,7 \\
\hline 19 & LNAS & 80 & 80 & 85 & 81,7 \\
\hline 20 & LAGL & 86 & 86 & 86 & 86,0 \\
\hline 21 & LTHL & 84 & 86 & 87 & 85,7 \\
\hline 22 & MRZE & 75 & 62 & 70 & 69,0 \\
\hline 23 & MSHL & 86 & 86 & 86 & 86,0 \\
\hline 24 & MGHW & 86 & 86 & 87 & 86,3 \\
\hline 25 & MPJL & 86 & 86 & 86 & 86,0 \\
\hline 26 & MGFR & 82 & 75 & 75 & 77,3 \\
\hline 27 & MGMY & 82 & 82 & 84 & 82,7 \\
\hline 28 & MRTW & 80 & 80 & 82 & 80,7 \\
\hline 29 & MISR & 82 & 82 & 84 & 82,7 \\
\hline 30 & MIPK & 86 & 86 & 86 & 86,0 \\
\hline 31 & MRAV & 88 & 86 & 88 & 87,3 \\
\hline 32 & MLRP & 80 & 82 & 75 & 79,0 \\
\hline 33 & MLAH & 82 & 83 & 85 & 83,3 \\
\hline 34 & MFYH & 88 & 87 & 88 & 87,7 \\
\hline 35 & MRFZ & 83 & 83 & 85 & 83,7 \\
\hline 36 & MARS & 88 & 87 & 88 & 87,7 \\
\hline 38 & MOK & 84 & 84 & 87 & 85,0 \\
\hline 39 & NBLH & 82 & 82 & 84 & 82,7 \\
\hline
\end{tabular}

\begin{tabular}{|l|l|l|l|l|l|}
\hline 40 & NRJH & 87 & 86 & 87 & 86,7 \\
\hline 41 & NDFH & 82 & 82 & 82 & 82,0 \\
\hline 42 & NSTI & 87 & 86 & 87 & 86,7 \\
\hline \multicolumn{7}{|l}{ Rata-Rata Nilai Kelas } & 84,0 \\
\hline
\end{tabular}

Dari tabel diatas dapat diketahui bahwa nilai peserta didik yang tertinggi yaitu 87 dan nilai terendah adalah 69. SKM Bahasa Indonesia di SMK Antartika 2 Sidoarjo yaitu 75. Dengan demikian dapat disimpulkan bahwa kemampuan berbicara bahasa Indonesia peserta didik kelas X Ak-2 pada tema Laporan Hasil Observasi telah memenuhi standar kelulusan minimal.

Peneliti juga menggunakan angket untuk mengetahui respon peserta didik terhadap pembelajaran menggunakan media Boneka Tangan Angket diberikan pada masing-masing peserta didik setelah proses pembelajaran berlangsung. Angket yang diberikan merupakan angket tertutup yang berisi delapan butir pertanyaan.

Tabel 4.2 Angket Penerapan Media Boneka Tangan

\begin{tabular}{|c|l|c|l|l|l|}
\hline \multirow{2}{*}{$\begin{array}{c}\text { No } \\
.\end{array}$} & \multirow{2}{*}{ Pertanyaan } & \multicolumn{3}{|c|}{ Opsi Jawaban } \\
\cline { 2 - 5 } & $\begin{array}{l}\text { Anda merasa } \\
\text { senang } \\
\text { mengikuti } \\
\text { PBM bahasa } \\
\text { Indonesiadeng } \\
\text { an } \\
\text { menggunakan } \\
\text { media Boneka } \\
\text { Tangan. }\end{array}$ & 31 & 9 & - & - \\
\hline 2 & $\begin{array}{l}\text { Media Boneka } \\
\text { Tangan mudah } \\
\text { digunakan. }\end{array}$ & 24 & 16 & - & - \\
\hline 3 & $\begin{array}{l}\text { Pemilihan } \\
\text { media Boneka } \\
\text { Tangan sesuai } \\
\text { untukketeramp } \\
\text { ilan berbicara } \\
\text { bahasa } \\
\text { Indonesia. }\end{array}$ & 23 & 14 & 3 & - \\
\hline 4 & $\begin{array}{l}\text { Media Boneka } \\
\text { Tangan }\end{array}$ & 26 & 14 & - & - \\
\hline
\end{tabular}


Tahun XI, No. 20, April 2015

\begin{tabular}{|l|l|l|l|l|l|}
\hline & $\begin{array}{l}\text { membuat Anda } \\
\text { bersemangat } \\
\text { dalam belajar } \\
\text { bahasa } \\
\text { Indonesia. }\end{array}$ & & & & \\
\hline 5 & $\begin{array}{l}\text { Media Boneka } \\
\text { Tangan dapat } \\
\text { membantu } \\
\text { Anda } \\
\text { dalamberbicara } \\
\text { bahasa } \\
\text { Indonesia. }\end{array}$ & 7 & 29 & 4 & - \\
\hline 6 & $\begin{array}{l}\text { Anda lebih } \\
\text { berani } \\
\text { berbicara } \\
\text { bahasa } \\
\text { Indonesia pada } \\
\text { tema Laporan } \\
\text { Hasil } \\
\text { Observasi } \\
\text { setelah } \\
\text { menggunakan } \\
\text { media Boneka } \\
\text { Tangan. }\end{array}$ & 20 & 17 & 3 & - \\
\hline 7 & $\begin{array}{l}\text { Boneka } \\
\text { Tangan dapat } \\
\text { menambah } \\
\text { kosakata } \\
\text { bahasa } \\
\text { Indonesia } \\
\text { Anda. }\end{array}$ \\
\hline 8 & $\begin{array}{l}\text { Penggunaan } \\
\text { media Boneka } \\
\text { Tangan dalam } \\
\text { pembelajaran } \\
\text { bahasa } \\
\text { Indonesia } \\
\text { perlu } \\
\text { dikembangkan. }\end{array}$ & 25 & 13 & 2 & - \\
\hline
\end{tabular}

Data hasil observasi juga membantu peneliti untuk mengetahui penerapan media Boneka Tangan. Pengisian lembar observasi dilakukan observer pada saat proses pembelajaran menggunakan media Boneka Tangan. Tabel berikut merupakan hasil observasi selama proses pembelajaran di kelas $\mathrm{X}$ Ak-2 dengan menggunakan media Boneka Tangan.
Tabel 4.3 Lembar Observasi Penerapan Media Boneka Tangan

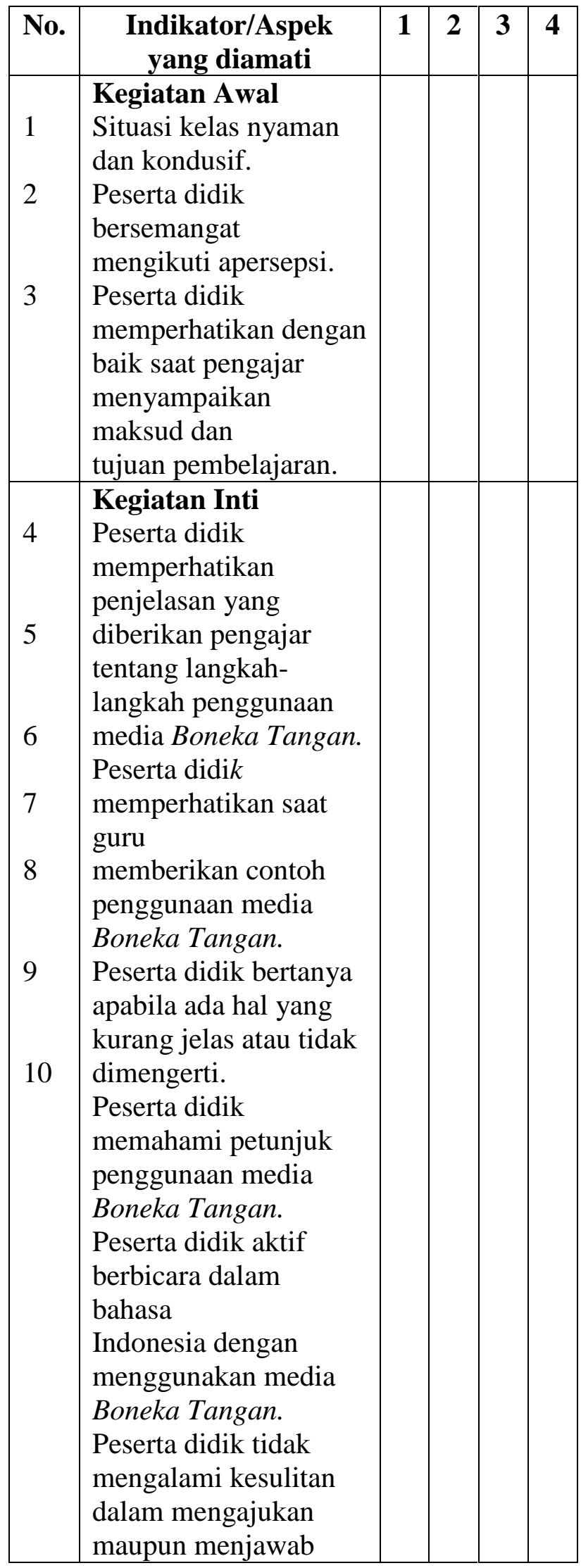




\begin{tabular}{|l|l|l|l|l|}
\hline & $\begin{array}{l}\text { pertanyaan. } \\
\text { Pembelajaran dengan } \\
\text { menggunakan } \\
\text { media Boneka Tangan } \\
\text { berjalan lancar dan } \\
\text { sesuai dengan yang } \\
\text { direncanakan. }\end{array}$ & & & \\
\hline 11 & $\begin{array}{l}\text { Penutup } \\
\text { Peserta didik mampu } \\
\text { menyimpulkan hasil } \\
\text { belajar. }\end{array}$ & & $\sqrt{ }$ & \\
\hline
\end{tabular}

Keterangan: $1=$ Kurang Baik

$2=$ Cukup Baik

$3=$ Baik

$4=$ Sangat Baik

\section{E. PEMBAHASAN}

Berdasarkan pada penelitian dengan menerapkan media Boneka Tangan, peneliti mendapati beberapa temuan pada penelitian tersebut. Temuan yang pertama yaitu dengan adanya penerapan media Boneka Tangan, peserta didik menjadi sangat kompak dalam bekerja sama dengan kelompok. Selain itu media Boneka Tangan juga merupakan sebuah media yang membuat peserta didik tertarik untuk mengikuti pembelajaran bahasa Indonesia. Hal ini dapat dibuktikan pada saat media Boneka Tangan diterapkan di kelas X Ak-2, peserta didik menjadi lebih aktif.

Pada saat proses pembelajaran dengan menggunakan media Boneka Tangan peserta didik terlihat sangat tertarik untuk mengikuti pembelajaran. Para peserta didik sangat antusias untuk berbicara dengan menggunakan media Boneka Tangan tersebut. Media mediaboneka tangan merupakan boneka yangdigerakkan oleh seseorang dengan caraseluruh jari-jari tangannya dimasukkan kebawah pakaian boneka yang dijadikansebagai media pembelajaran pendidikanuntuk anak yang digunakan untukmenyalurkan pesan dalam bercerita.Hal ini didukung oleh pernyataan Sudjana dan Rivai (2002:2) yang mengemukakan beberapa manfaat media dalam proses belajar peserta didik, yaitu: (1) dapat menumbuhkan motivasi belajar peserta didik karena pengajaran akan lebih menarik perhatian mereka; (2) makna bahan pengajaran akan menjadi lebih jelas sehingga dapat dipahami peserta didik dan memungkinkan terjadinya penguasaan serta pencapaian tujuan pengajaran; (3) metode mengajar akan lebih bervariasi, tidak sematamata didasarkan atas komunikasi verbal melalui kata-kata; dan (4) peserta didik lebih banyak melakukan aktivitas selama kegiatan belajar, tidak hanya mendengarkan tetapi juga mengamati, mendemonstrasikan, melakukan langsung, dan memerankan.

Dengan adanya penerapan media ini para peserta didik lebih berani untuk berbicara, karena di dalam media tersebut para peserta didik dianjurkan untuk lebih aktif berbicara. Menurut Leo Kanner (dalam Anggani, 2000:55) bahwa keuntungan dari bermain tentang persepsi pendengaran dapat membentuk: (a) meningkatkan motivasi, minat, percaya diri dan membantu membentuk kepribadian anak; (b) belajar menggunakan bahasa dengan baik agar dapat menjalin pertemanan (perkembangan emosional); (c) meningkatkan kemampuan bicara; (d) belajar mengungkapkan diri secara spontan; (e) memiliki kekuatan ingatan pendengaran; (f) memahami, menghubungkan dan mengutarakan pengetahuannya dalam bentuk bahasa yang ekspresif.

Keberanian peserta didik untuk berbicara diperkuat oleh hasil angket yang disebar oleh peneliti pada peserta didik. Hasil angket pada butir keenam menjelaskan bahwa lebih dari separuh peserta didik menyatakan bahwa mereka setuju untuk lebih berani berbicara setelah menggunakan media Boneka Tangan. Sedangkan hanya sedikit peserta didik yang menyatakan tidak setuju pada poin keenam angket tersebut.

Data dari hasil penilaian kemampuan berbicara peserta didik kelas X Ak-2 SMK Antartika 2 Sidoarjo diketahui sebanyak 97,6\% peserta didik memenuhi standar kelulusan minimal, dan $2,3 \%$ peserta didik tidak memenuhi standar. Dengan demikian dapat disimpulkan bahwa kemampuan berbicara peserta didik kelas X Ak-2 pada tema Laporan Hasil Observasi telah memenuhi standar kelulusan minimal. 


\section{F. Simpulan dan Saran}

\section{Simpulan}

Berdasarkan temuan penelitian dan pembahasan dapat disimpulkan bahwa 1) penerapan media Boneka Tangan pada keterampilan berbicara peserta didik kelas X Ak-2 SMK Antratika 2 Sidoarjo berjalan dengan baik. Keinginan peserta didik kelas $\mathrm{X}$ Ak-2 untukmengikuti proses pembelajaran bahasa Indonesia sangat terlihat dan mereka tertarikdengan adanya penerapan media Boneka Tangan. Proses pembelajaran sendiri berjalandengan baik dan sangat lancar. Para peserta didik sangat antusias dan lebih termotivasi untukmengikuti proses pembelajaran, 2) hasil belajar peserta didik kelas X Ak-2 SMK Antartika 2 Sidoarjo diketahui sebanyak $97,6 \%$ peserta didik memenuhi standar kelulusan minimal, dan $2,3 \%$ peserta didik tidak memenuhi standar.

\section{Saran}

Berdasarkan hasil simpulan di atas, saran yang diberikan peneliti adalah bagi peneliti lain yang akan melakukan penelitian yang sejenis, sebaiknya peneliti memperhitungkan dana, waktu, dan tenaga yang dibutuhkan dalam penelitian sehingga penelitian dapat berjalan sesuai dengan harapan peneliti.

\section{DAFTAR PUSTAKA}

Arsyad,

Azhar.2005.

Media

Pembelajaran.Edisi kedua.Jakarta: Raja Grafindo Persada.

Gunarti, W. 2010.Metode Pengembangan Perilaku dan Kemampuan Anak Usia Dini. Jakarta: Universitas Terbuka.

Heinich, R., et. al. (1996) Instructional Media and Technologies for Learning. New Jersey: Prentice Hall, Englewood Cliffs.
Kemp, J. E. 1985. The Instructional Design Process by Harper \& Row. Publishers Inc.

Pribadi, Benny A. 2004. Model Desain Sistem Pembelajaran. Jakarta: Dian Rakyat.

Miarso, Yusuf H.2004. Menyemai Benih Teknologi Pendidikan. Jakarta: Pustekkom DIKNAS.

Triutami, I Gusti Ayu Arry Diah. 2014. Penerapan Metode Bercerita dengan Berbantuan Media Boneka Tangan untuk Meningkatkan Perkembangan Bahasa Anak. e-Journal PG-PAUD Universitas Pendidikan Ganesha.

Sadirman, Arif. dkk. 1996. Media Pendidikan. Jakarta: Raja Grafindo Persada.

Sudjana, Mania dan Ahmad Rivai. 2002. Media Pembelajaran. Bandung: Sinar Baru Algasindo.

Sudono, Anggani. 1995. Sumber Belajar dan Alat Permainan untuk Pendidikan Anak Usia Dini. Jakarta: PT. Grasindo.

Suharsimi, Arikunto. 2002. Prosedur Penelitian. Jakarta: Pusat Anta Universitas dengna Rajawali.

(http://www.ayahbunda_online.com//infoayah bunda/search_detail_asp).

http://adrianade.blogspot.com/2013/06/pengert ian-dialog.html. 
Tahun XI, No. 20, April 2015 